\title{
Physical activity, body fat and experimental cardiac necrosis
}

\author{
By JANA PAŘ́́ZKOVÁ AND EVA FALTOVÁ \\ Physical Culture Research Institute and \\ Institute of Physiology \\ Czechoslovak Academy of Sciences, Prague, Czechoslovakia
}

(Received 3 September 1968-Accepted I I $\mathscr{f} u l y$ I969)

\begin{abstract}
I. The effects of varying levels of physical activity were tested in rats, starting at ages of 21 , 32 and 55 days and continuing until $90,100,125$ and 205 days.

2. Weight changes did not differ significantly between the exercise groups, except in the groups tested up to 205 days, when both the exercised group and the group with limited activity were significantly lighter than the control group.

3. The weight of the soleus muscle was significantly greater in the exercised rats compared with controls and rats with limited activity, except in the oldest age-group. The weight of the tibialis anticus muscle did not differ significantly between the different exercise regimes.

4. Heart weight was not significantly affected by the exercise regime, except that in rats studied from 55 to 125 days; the group with limited activity had significantly lighter hearts than those in the control group or the exercised group.

5. The percentage body fat was lower in the exercised group compared with the limited activity group, and was less than the control group in both the rats studied up to 205 days and those studied from 21 to 90 days.

6. Isoprenaline produced less cardiac damage in the exercised rats than in controls or in rats with limited activity. Animals who died following injection of isoprenaline had a higher percentage body fat than those animals with minimal cardiac damage.
\end{abstract}

A number of clinical studies suggest a relationship between increased incidence of cardiovascular diseases and low physical activity (Morris, Heady, Raffle, Roberts \& Parks, I953; Kagan, I960; Brunner \& Manelis, I960; Kannel, 1967). The reason for this is not clear, but lack of muscular work and activity may be one of the factors which promote these diseases (Frank, 1966; Raab, 1965; Montoye, 1967).

Animals adapted to increased physical activity resemble younger animals in certain aspects of fat metabolism (Pařizková \& Staňková, 1967). Experiments have therefore been carried out in which the effects of exercise on rats have been studied at different ages. As well as examining differences in muscle size and in body fat, the effect of isoprenaline has also been examined since it has been shown (Rona, Chappel, Balasz \& Gaudry, 1959a) that the cardiotoxicity of isoprenaline is less in younger and lighter animals than in older and heavier ones. The lower mortality is closely related to the proportion of body fat in young rats (Faltová \& Pařízková, 1969) who display a high degree of spontaneous physical activity (Smith \& Dugal, 1965).

\section{EXPERIMENTAL}

A total of 193 male Wistar rats was included. There were five groups of animals studied over different periods of time (see Table I). Each age-group was further subdivided and the subgroups had different regimens of physical activity ranging 
from virtual inactivity to moderately severe treadmill exercise. Details of numbers in each group and subgroup are given in Table $\mathrm{x}$, together with details of physical activity and cage sizes.

Animals were fed on a standard Larsen diet and had water ad lib. (Pařizková \& Staňková, 1964).

Table I. Details of exercise regimen and number of rats in each group and subgroup

\begin{tabular}{|c|c|c|c|c|c|c|}
\hline \multirow[b]{2}{*}{ Group } & \multicolumn{4}{|c|}{ Activity regime } & \multirow[b]{2}{*}{ Total } & \multirow{2}{*}{$\begin{array}{l}\text { Period studied } \\
\text { (days) }\end{array}$} \\
\hline & $\mathbf{r}$ & 2 & 3 & 4 & & \\
\hline I & I I & 12 & 14 & 14 & $5^{I}$ & $55-100$ \\
\hline 2 & 16 & 9 & $\cdot$ & 18 & 43 & $55^{-125}$ \\
\hline 3 & Io & 13 & 10 & 18 & $5 \mathrm{I}$ & $32-125$ \\
\hline 4 & . & 9 & . & 9 & 18 & $2 I-90$ \\
\hline 5 & 10 & 10 & . & IO & 30 & $2 x-205$ \\
\hline Total & 47 & 53 & 24 & 69 & . & . \\
\hline
\end{tabular}

Activity: (I) Animals in separate cages, size $8.5 \times 3.5$ in. = limited activity.

(2) Animals in groups up to 5 in each cage $(16.0 \times 9.0$ in.) $=$ control.

(3) Ditto, but with earth in cages = control conditions + digging activity.

(4) Animals on treadmill $20 \mathrm{~m} / \mathrm{min} 90 \mathrm{~min} /$ day $=$ increased activity.

(It was expected that physical activity would increase from $\mathrm{I}<2<3<4$.)

Table 2. Dosage schedule of isoprenaline injections per kg body-weight

$\begin{array}{ccc}\text { Group } & \text { Dose I }(\mathrm{mg}) & \text { Dose 2 }(\mathrm{mg}) \\ \text { I } & 40 & 20 \\ 2 & 80 & 40 \\ 3 & 80 & 80 \\ 4 & 80 & 80 \\ 5 & 20 & 5\end{array}$

Myocardial necrosis. Two doses of isoprenaline were given at an interval of $24 \mathrm{~h}$, subcutaneously, to each rat at the end of the period of study (Rona, Chappel, Balasz \& Gaudry, $1959 b$ ). The doses used are set out in 'Table 2. The rats were decapitated $24 \mathrm{~h}$ after the second injection; the heart was removed and the degree of cardiac damage estimated, using the scale described by Rona et al. (1959a,b), where

$0=$ no damage, $\mathbf{I}=$ diffuse pale areas at tip of ventrical, $2=$ limited necrosis at tip of ventricle, $3=$ necrosis involving one-third of left ventricle, $4=$ necrosis involving more than half of left ventricle, $5=$ animals dying.

Body fat. This was estimated gravimetrically, using a chloroform extract of the carcass saponified in a mixture of $30 \% \mathrm{KOH}$ in $50 \%$ ethanol. In the final evaluation of results, only those from animals in which all indicators could be estimated were used.

Measurement of oxygen consumption and rectal temperature. Following the administration of isoprenaline, rectal temperature was measured with a thermocouple and oxygen consumption was assessed using an interferometer (L. Staňková \& L. Jánsky, unpublished results). 


\section{RESULTS}

In Table 3 are set out all the significant differences observed in the various measurements made. In this table are included all the comparisons of, on the one hand, limited activity and, on the other hand, the exercised rats running on the treadmill with the control group.

\section{Table 3. Table of significant differences, comparing rats with limited activity} and exercising rats with control group

(Numbers refer to tables, i.e.: $4(a)=$ total body-weight; $4(b)=$ fat-free body-weight; $5=$ heart weight; $7(a)=$ weight of soleus muscle; $7(b)=$ weight of soleus muscle $(\mathrm{mg}) / \mathrm{ro0} \mathrm{g}$ body-weight; $7(c)=$ weight of soleus muscle $(\mathrm{mg}) / \mathrm{roo} \mathrm{g}$ fat-free body-weight; 8 = body fat (\% total body-weight)

\begin{tabular}{|c|c|c|c|c|c|c|}
\hline \multirow{3}{*}{$\begin{array}{c}\text { Group } \\
\text { I }\end{array}$} & \multicolumn{3}{|c|}{ Limited activity } & \multicolumn{3}{|c|}{ Exercised } \\
\hline & $4(a)$ & 5 & $7(a),(b),(c)$ & $4(a)$ & . & . \\
\hline & - & - & - & - & . & \\
\hline \multirow[t]{2}{*}{2} & . & . & . & . & $7(a)$ & . \\
\hline & . & . & . & . & + & . \\
\hline \multirow[t]{2}{*}{3} & . & . & $7(b),(c)$ & $4(b)$ & $7(a),(b)$ & . \\
\hline & . & . & - & + & + & . \\
\hline \multirow[t]{2}{*}{4} & . & . & . & $\cdot$ & $\cdot$ & 8 \\
\hline & & . & . & $\cdot$ & $\cdot$ & - \\
\hline \multirow[t]{2}{*}{5} & $4(a)$ & . & 8 & $4(a),(b)$ & $7(b)$ & 8 \\
\hline & - & . & - & - & + & - \\
\hline
\end{tabular}

Table 4. Total and lean fat-free body-weight in male rats on different exercise regimes

\begin{tabular}{|c|c|c|c|c|c|c|c|c|c|c|c|}
\hline \multirow{2}{*}{$\begin{array}{c}\text { Age } \\
\text { expt } \\
\text { began } \\
\text { (days) }\end{array}$} & \multirow{2}{*}{$\begin{array}{l}\text { Age } \\
\text { expt } \\
\text { ended } \\
\text { (days) }\end{array}$} & \multirow{2}{*}{ Group } & & \multicolumn{4}{|c|}{ (a) Total body-weight (g) } & \multicolumn{4}{|c|}{ (b) Fat-free body-weight (g) } \\
\hline & & & & $\stackrel{\mathbf{I}}{\text { Limited }}$ & $\stackrel{2}{\text { Controls }}$ & $\stackrel{3}{\text { Earth }}$ & $\stackrel{4}{\text { Running }}$ & $\stackrel{\text { I }}{\text { Limited }}$ & $\stackrel{2}{\text { Controls }}^{2}$ & $\stackrel{3}{\text { Earth }}$ & $\stackrel{4}{\text { Running }}$ \\
\hline 55 & 100 & $\mathbf{I}$ & $\begin{array}{l}\bar{x} \\
s\end{array}$ & $\begin{array}{r}251 \cdot 0 \\
18 \cdot 7\end{array}$ & $\begin{array}{r}274.0 \\
28.0\end{array}$ & $\begin{array}{r}276.0 \\
16.7\end{array}$ & $\begin{array}{r}253 \cdot 4 \\
19 \cdot 1\end{array}$ & $\begin{array}{r}229^{\circ} 5 \\
\mathrm{r} 5^{\cdot 2}\end{array}$ & $\begin{array}{r}251 \cdot 0 \\
26.0\end{array}$ & $\begin{array}{r}250.4 \\
19.1\end{array}$ & $\begin{array}{r}235.6 \\
17.8\end{array}$ \\
\hline 55 & 125 & 2 & $\begin{array}{l}\bar{x} \\
s\end{array}$ & $\begin{array}{r}282 \cdot 7 \\
26 \cdot 0\end{array}$ & $\begin{array}{r}271 \cdot 6 \\
27 \cdot 3\end{array}$ & . & $\begin{array}{r}284 \cdot 7 \\
24 \cdot 0\end{array}$ & $\begin{array}{r}257 \cdot 0 \\
25 \cdot 0\end{array}$ & $\begin{array}{r}25 I \cdot 5 \\
2 I \cdot 0\end{array}$ & . & $\begin{array}{r}263 \cdot I \\
20 \cdot I\end{array}$ \\
\hline 32 & 125 & 3 & $\begin{array}{l}\bar{x} \\
s\end{array}$ & $\begin{array}{r}25 I \cdot 0 \\
28 \cdot 5\end{array}$ & $\begin{array}{r}264 \cdot 3 \\
35 \cdot 4\end{array}$ & $\begin{array}{r}266.9 \\
33.8\end{array}$ & $\begin{array}{r}280 \cdot 1 \\
89 \cdot 5\end{array}$ & $\begin{array}{r}217 \cdot 3 \\
25 \cdot 7\end{array}$ & $\begin{array}{r}225 \cdot 6 \\
35 \cdot 1\end{array}$ & $\begin{array}{r}232.4 \\
29 \cdot 9\end{array}$ & $\begin{array}{r}243 \cdot 1 \\
27 \cdot 8\end{array}$ \\
\hline $2 \mathrm{I}$ & 90 & 4 & $\begin{array}{l}\bar{x} \\
s\end{array}$ & . & $\begin{array}{r}300 \cdot 1 \\
16 \cdot 7\end{array}$ & . & $\begin{array}{r}291 \cdot 3 \\
20 \cdot 7\end{array}$ & . & $\begin{array}{r}247 \cdot 6 \\
19 \cdot 2\end{array}$ & . & $\begin{array}{r}244 \cdot 2 \\
I 7 \cdot I\end{array}$ \\
\hline 2 I & 205 & 5 & $\begin{array}{l}\bar{x} \\
s\end{array}$ & $\begin{array}{r}420 \cdot 3 \\
32 \cdot 9\end{array}$ & $\begin{array}{r}464 \cdot 0 \\
33 \cdot 3\end{array}$ & . & $\begin{array}{r}389.8 \\
30.6\end{array}$ & $\begin{array}{r}349^{\circ} 6 \\
30 \cdot 3\end{array}$ & $\begin{array}{r}379 \cdot 5 \\
49 \cdot 3\end{array}$ & . & $\begin{array}{r}334^{\cdot 2} \\
34^{\cdot 2}\end{array}$ \\
\hline
\end{tabular}

The mean values for total weight and fat-free, lean body weight are presented in Table 4. Significant differences of total body-weight relating to activity levels were observed in group 1 rats (studied from 55 to roo days) and in group 5 rats (studied from 21 to 205 days). In both groups animals kept in single cages were lighter than controls, and the group I rats were lighter than the rats kept in a cage with earth. 
There were a number of significant differences, as shown in Table 3 , depending on the age of the animals.

The variations in fat-free body-weight did not appear to be significant except that in group 3 the controls were lighter than the animals running on the treadmill, but in group 5 an opposite effect was observed (Table 3 ).

Table 5. Mean values of heart weights $(\mathrm{mg})$ in male rats on different exercise regimes

\begin{tabular}{|c|c|c|c|c|c|}
\hline Group & & $\stackrel{\text { I }}{\text { Limited }}$ & $\stackrel{2}{2}$ Controls & $\stackrel{3}{\text { Earth }}$ & $\stackrel{4}{\text { Running }}$ \\
\hline I & $\begin{array}{l}\bar{x} \\
s\end{array}$ & $\begin{array}{r}836 \cdot 0 \\
57 \cdot 8\end{array}$ & $\begin{array}{l}992 \cdot 0 \\
\text { I } 33 \cdot 7\end{array}$ & $\begin{array}{l}907.0 \\
100.5\end{array}$ & $\begin{array}{r}922 \cdot 0 \\
77 \cdot 1\end{array}$ \\
\hline 2 & $\begin{array}{l}\bar{x} \\
s\end{array}$ & $\begin{array}{l}887 \cdot 7 \\
274 \cdot 8\end{array}$ & $\begin{array}{r}900 \cdot 2 \\
84.4\end{array}$ & . & $\begin{array}{r}925^{\circ} 4 \\
73^{\circ} \mathrm{I}\end{array}$ \\
\hline 3 & $\begin{array}{l}\bar{x} \\
s\end{array}$ & $\begin{array}{l}972 \cdot 7 \\
\text { I03.0 }\end{array}$ & $\begin{array}{r}1092 \cdot 3 \\
95^{\circ} 0\end{array}$ & $\begin{array}{r}1097.3 \\
115.2\end{array}$ & $\begin{array}{r}\operatorname{II} 5 \cdot 2 \\
78 \cdot 1\end{array}$ \\
\hline 4 & $\begin{array}{l}\bar{x} \\
s\end{array}$ & . & $\begin{array}{r}\text { I } 26.4 \\
98 \cdot 3\end{array}$ & . & $\begin{array}{r}\mathbf{1 0 9 4 ^ { \circ } 5} \\
98.2\end{array}$ \\
\hline 5 & $\begin{array}{l}\bar{x} \\
s\end{array}$ & $\begin{array}{r}1185^{\circ} 0 \\
123^{\circ} 7\end{array}$ & $\begin{array}{r}1145^{\circ} 9 \\
80^{\circ} 3\end{array}$ & : & $\begin{array}{r}1144^{\circ} 5 \\
86 \cdot 9\end{array}$ \\
\hline
\end{tabular}

Table 6. Mean values of adrenal weights $(\mathrm{mg})$ in rats on different exercise regimes

\begin{tabular}{|c|c|c|c|c|c|}
\hline Group & & $\stackrel{\mathbf{1}}{\text { Limited }}$ & $\stackrel{2}{\text { Controls }}$ & $\stackrel{3}{\mathbf{3}}$ & $\stackrel{4}{\text { Running }}$ \\
\hline I & $\begin{array}{l}\bar{x} \\
s\end{array}$ & $\begin{array}{l}5 \mathrm{Y} \cdot \mathrm{I} \\
10 \cdot 9\end{array}$ & $\begin{array}{r}47 \cdot 9 \\
6 \cdot 3\end{array}$ & $\begin{array}{l}58 \cdot 0 \\
11 \cdot 0\end{array}$ & $\begin{array}{r}47 \cdot 1 \\
4 \cdot 9\end{array}$ \\
\hline 2 & $\begin{array}{l}\bar{x} \\
s\end{array}$ & $\begin{array}{r}47 \cdot 0 \\
5 \cdot 1\end{array}$ & $\begin{array}{r}49^{\circ} \circ \\
9 \cdot 7\end{array}$ & . & $\begin{array}{r}55^{\circ} 0 \\
7 \cdot 3\end{array}$ \\
\hline 3 & $\begin{array}{l}\bar{x} \\
s\end{array}$ & $\begin{array}{r}40 \cdot 3 \\
2 \cdot 5\end{array}$ & $\begin{array}{r}42 \cdot 2 \\
6 \cdot 9\end{array}$ & $\begin{array}{r}44.2 \\
4.7\end{array}$ & $\begin{array}{r}42 \cdot 5 \\
4 \cdot 3\end{array}$ \\
\hline 4 & $\begin{array}{l}\bar{x} \\
s\end{array}$ & . & $\begin{array}{r}44 \cdot 7 \\
7 \cdot 8\end{array}$ & . & $\begin{array}{r}50.8 \\
3.2\end{array}$ \\
\hline 5 & $\begin{array}{l}\bar{x} \\
s\end{array}$ & $\begin{array}{r}48 \cdot 8 \\
4.9\end{array}$ & $\begin{array}{r}49^{\cdot I} \\
5^{\cdot I}\end{array}$ & . & $\begin{array}{r}49^{\circ} 5 \\
4^{\cdot} \cdot \mathrm{I}\end{array}$ \\
\hline
\end{tabular}

In Table 5 the mean heart weight of the rats is set out. Heart weight was significantly greater in treadmill rats (4) than in the limited activity group (I) in groups I and 3 , but there was no such significant difference between the corresponding animals in groups 2 and 5 (Table 3 ). Comparison of groups 2 and 5 showed that there was evidence of only slight increase in heart size from the age of 90 days to 205 , in spite of both total and fat-free body-weight increasing by approximately $50 \%$ (Table 4).

Adrenal weights are set out in Table 6 . The only significant difference attributable to exercise was that, in the group 2 rats, running animals (4) had larger adrenals than the rats kept in single cages. The weight of the tibialis anticus muscle was not signifi- 
Vol. 24

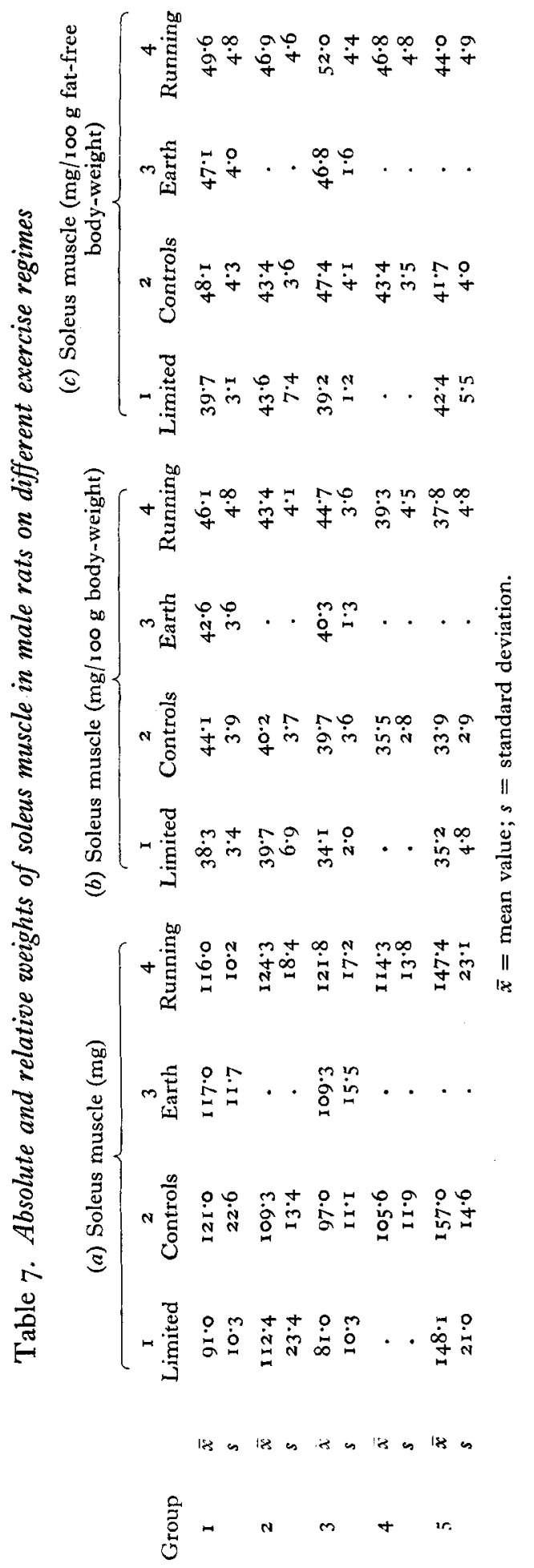


cantly affected by the exercise regime, but the soleus muscle was significantly heavier in the treadmill rats than in the limited activity rats in groups I and 3 (Tables 3 and 7 ).

The proportion of body fat was also lower in all the groups in the treadmill animals compared with limited activity although the difference was only significant in groups

Table 8. Proportion of fat, mortality and cardiac damage, in rats, following the injection of isoprenaline. Cardiac damage assessed in terms of scale running from $\circ$ to 5

\section{Group}

I

3

4

5

2

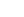

Body fat ( $\%$ total
body-weight)

No. of rats died

No. of rats in group

Mean cardiac score of survivors

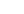

Body fat (\% total body-weight)

No. of rats died

No. of rats in group

Mean cardiac score of survivors

Body fat (\% total body-weight)

No. of rats died

No. of rats in group

Mean cardiac score of survivors

Body fat (\% total body-weight)

No. of rats died

No. of rats in group

Mean cardiac score of survivors

Body fat (\% total body-weight)

No. of rats died

No. of rats in group

Mean cardiac score of survivors

$\bar{x}=$ mean value $; s=$ standard deviation.

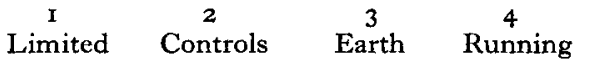

$\begin{array}{ccccc}\ddot{x} & 8 \cdot 4 & 8 \cdot 2 & 9 \cdot \mathrm{I} & 6 \cdot 9 \\ s & 2 \cdot 4 & 1 \cdot 4 & 2 \cdot 3 & 1 \cdot 2 \\ & 2 & 2 & 7 & 2 \\ & \text { II } & 12 & 14 & 14 \\ & \text { I.7 } & 1 \cdot 7 & 2 \cdot 6 & \text { I.6 }\end{array}$

$\begin{array}{lllll}\bar{x} & 9.0 & 7.4 & - & 7.2\end{array}$

$\begin{array}{lllll}s & 2.5 & 2 \cdot 2 & - & 1 \cdot 7\end{array}$

$\begin{array}{llll}8 & 1 & - & 7\end{array}$

$16 \quad 9 \quad-\quad 18$

$\begin{array}{llll}I \cdot 9 & I \cdot 4 & \end{array}$

$\begin{array}{lllll}\bar{x} & 13 \cdot 3 & \mathrm{I} \cdot 2 & 11 \cdot 0 & \mathrm{II}\end{array}$

$\begin{array}{lllll}s & 2.8 & 3.4 & 1 \cdot 7 & 2 \cdot 9\end{array}$

$\begin{array}{rrrr}4 & 7 & 4 & 9 \\ 10 & 13 & 10 & 8\end{array}$

$2 \cdot 2 \quad 2 \cdot 0 \quad 2 \cdot 0 \quad 1 \cdot 3$

$\begin{array}{llrll}\bar{x} & - & \mathrm{I} 1 \cdot 9 & - & 8 \cdot 0 \\ s & - & \mathrm{I} \cdot 9 & - & \mathrm{I} \cdot 8\end{array}$

- 6 - 5

$\begin{array}{lll}9 & 2.3 & -\end{array}$

$\begin{array}{lllll}\bar{x} & 12.4 & 17.0 & - & 9.4\end{array}$

$\begin{array}{llll}2 \cdot 9 & 4 \cdot 1 & - & 1 \cdot 4\end{array}$

$5 \quad 7 \quad-3$

$\begin{array}{cccc}10 & 10 & - & 10 \\ 1.4 & 1.7 & - & 1 \cdot 1\end{array}$

Table 9. Mean weight $(\mathrm{g})$ and proportion of fat for rats with a score of $\mathrm{I}$ (least damage) and a score of 5 (animals died)

\begin{tabular}{|c|c|c|c|c|c|c|c|c|}
\hline \multirow[b]{3}{*}{ Group } & \multicolumn{4}{|c|}{ Body-weight } & \multicolumn{4}{|c|}{ Body fat ( $\%$ total body-weight) } \\
\hline & \multicolumn{2}{|c|}{ Score 5} & \multicolumn{2}{|c|}{ Score I } & \multicolumn{2}{|c|}{ Score 5} & \multicolumn{2}{|c|}{ Score I } \\
\hline & $\bar{x}$ & $s$ & $\bar{x}$ & $s$ & $\bar{x}$ & $s$ & $\bar{x}$ & $s$ \\
\hline 1 & $295^{\circ} \circ$ & I $7 \cdot 8$ & 270.4 & 40.7 & $9 \cdot 2$ & $2 \cdot 3$ & $6 \cdot 8$ & $2 \cdot 0$ \\
\hline 2 & $275^{\circ} \circ$ & $21 \cdot 0$ & $26 I \cdot 5$ & $23 \cdot 1$ & $10 \cdot 4$ & $2 \cdot 3$ & $7 \cdot 4$ & $1 \cdot 3$ \\
\hline 3 & $279 \cdot 2$ & $30 \cdot 8$ & $274 \cdot 4$ & $3 I \cdot 4$ & $12 \cdot 9$ & $3 \cdot 6$ & $10 \cdot 2$ & I 3 \\
\hline 4 & 294.0 & - & 294.5 & - & $12 \cdot 9$ & $3 \cdot 6$ & $10 \cdot 2$ & I 3 \\
\hline 5 & $448 \cdot 7$ & $38 \cdot 4$ & $397 \cdot 3$ & $36 \cdot 0$ & I3:3 & $2 \cdot 8$ & II $\cdot 3$ & $3 \cdot 6$ \\
\hline
\end{tabular}


4 and 5 (Tables 3 and 8 ). The number of animals dying following the injections of isoprenaline was slightly less in the treadmill rats than in any of the other exercise regimes (Table 8). The average score for the grading of myocardial lesions followed a similar pattern. There was no evident relationship between the extent of myocardial lesions and the percentage of body fat. However the death rate did appear to increase as the percentage of body fat increased. The age at which the exercise regime began did not appear to affect either mortality rate or the extent of the myocardial lesions.

The results, irrespective of the different exercise regimes, were divided into two groups: rats with the most severe cardiac damage (grade 5) and those with the least evidence of damage (grade $\mathrm{r}$ ). The body-weights and percentage fat in the two groups

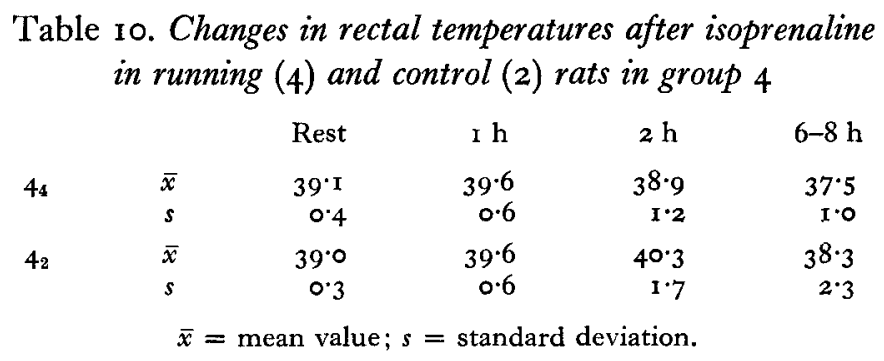

are set out in Table 9. Groups $I$ and 5 rats who had only slight cardiac lesions were significantly lighter than the rats who died after isoprenaline, and there was a similar but not significant difference in groups 2 and 3 . However, when the results are expressed as percentage body fat, there was a significant difference in groups I, 2 and 3 (Table 3 ).

The effect of isoprenaline on body temperature and oxygen consumption was complex. There was in most instances an increased oxygen consumption, which tended to be higher in the control rats. Rectal temperature rose rather higher in the control animals than in the exercised rats (Table IO).

\section{DISCUSSION}

There was no evident effect of the various exercise regimes on body-weight, except in the oldest rats in group 5 , where the rats exercised on the treadmill were significantly lighter and less fat than the control group. The presence or absence of earth in the cage did not appear to affect any of the results, i.e. there were no significant differences between subgroups 2 and 3 .

Heart size was in no instance significantly different when exercised and control animals were compared, nor was mortality following the injections of isoprenaline. However, the degree of cardiac damage was less in the exercised animals.

On the other hand, the results suggest that mortality rate and the percentage of body fat are related. The influence of physical activity manifests itself only when the body-weight and fat are reduced. When a comparison was made between all the animals who died following isoprenaline and those with the least cardiac damage, it was found that in all groups the latter had a lower percentage of body fat, and this 
was significant in groups $1-3$. An increased ratio of fat can interfere with radiation of excess heat (Quaade, 1963) produced by isoprenaline application and contribute inter alia to final insufficiency of the heart (Faltova \& Poupa, I969) which is relatively smaller in fatter animals. A comparison of the percentage body fat with the degree of cardiac damage as scored did not reveal an evident relationship.

Heart weight was affected by varying degrees of oedema due to the effect of isoprenaline, and this may have obscured the relationship with exercise, as previous work has shown that a significant effect of exercise can be demonstrated (Pařizková, Staňková, Fábry \& Koutecký, ı966; Pařízková, Koutecký \& Staňková, I966).

The main effect of exercise was an increase in the weight of the soleus muscle, but even this was only significant in groups $I$ and 3 . There was no demonstrable effect of the age at which the regime began or of its duration.

\section{REFERENCES}

Brunner, D. \& Manelis, G. (1960). Lancet ii, I049.

Faltová, E. \& Pařizková, J. (1969). Physiol. bohemoslov. (In the Press.)

Faitová, E. \& Poupa, O. (r969). Can. J. Physiol. Pharmacol. 47, 295.

Frank, C. W. (1966). Circulation 34, 1022.

Kagan, A. (ig6o). Proc. R. Soc. Med. 53, 18.

Kannel, W. B. (1967). Circulation 35, 734.

Montoye, H. J. (r967). Can. med. Ass. F. 96, 8r 3 .

Morris, J. N., Heady, J. A., Raffle, P. A. B., Roberts, C. G. \& Parks, J. W. (1953). Lancet ii, 1053.

Pař́zková, J., Koutecký, Z. \& Stan̆ková, L. (1966). Physiol. bohemoslov. 15, 237.

Pařízková, J. \& Staňková, L. (1964). Br. F. Nutr. 18, 325.

Pařízková, J. \& Stáňková, L. (1967). Nutritio Dieta 9, 43.

Pařízková, J., Staňková, L., Fábry, P. \& Koutecký, Z. (I966), Physiol. bohemoslov. 17, I77.

Quaade, F. ( 1963$)$. Lancet ii, 429.

Raab, W. (1965). Wien. klin. Wchshr, 77, 356.

Rona, G., Chappel, C. I., Balasz, T. \& Gaudry, R. (r959a). F. Geront. r4, I69.

Rona, G, Chappel, C. I., Balasz, T. \& Gaudry, R. (1959b). Archs Path. 67, 443.

Smith, L. C. \& Dugal, L. P. (1965). Can. F. Physiol. Pharmacol. 43, 852. 